DOI: https://doi.org/10.47405/mjssh.v6i5.781

\begin{tabular}{|c|c|}
\hline 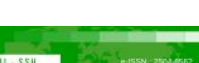 & Malaysian Journal of Social Sciences and Humanities (MJSSH) \\
\hline Malaysian Journal of & Volume 6, Issue 5, May 2021 \\
\hline (MJ-ssH) & e-ISSN : 2504-8562 \\
\hline & $\begin{array}{l}\text { Journal home page: } \\
\text { www.msocialsciences.com }\end{array}$ \\
\hline
\end{tabular}

\title{
Penggunaan M-Learning Sebagai Bahan Bantu Pengajaran dalam Kelas Pendidikan Khas
}

\author{
Norshila Binti Roslin ${ }^{1}$, Norshidah Mohamad Salleh ${ }^{1}$ \\ 1Fakulti Pendidikan, Universiti Kebangsaan Malaysia (UKM) \\ Correspondence: Norshidah Mohamad Salleh (nshidah@ukm.edu.my)
}

\begin{abstract}
Abstrak
Penggunaan teknologi moden seperti telefon bimbit dan tablet dapat membantu melaksanakan pengajaran menggunakan teknologi maklumat dan komunikasi. Dalam bidang pendidikan, perkembangan kurikulum dan pedagogi dalam pendidikan adalah dipengaruhi oleh perkembangan teknologi itu sendiri. Oleh hal yang demikian, penggunaan Mobile Learning (M-Learning) sebagai bahan bantu pengajaran guru dalam kelas Pendidikan Khas adalah lebih efektif dan seterusnya dapat meningkatkan kemahiran guru dalam penggunaan teknologi maklumat. Kajian tinjauan ini menggunakan pendekatan kuantitatif berbentuk deskriptif yang melibatkan peratusan, frekuensi, min dan sisihan piawai. Dalam kajian ini, kaedah persampelan bertujuan digunakan dalam kajian ini kerana kajian ini hanya melibatkan guru Pendidikan Khas dalam sebuah daerah di negeri Johor. Seramai 88 orang sampel yang terdiri daripada 28 buah sekolah kebangsaan, 2 buah sekolah jenis kebangsaan dan 14 buah sekolah menengah yang berada di bawah pentadbiran penuh Kementerian Pelajaran Malaysia. Dapatan kajian menunjukkan bahawa penggunaan, kemahiran dan sikap guru Pendidikan Khas terhadap penggunaan M-Learning sebagai bahan bantu pengajaran dan pembelajaran berada pada tahap tinggi. Implikasi daripada kajian ini menunjukkan bahawa hampir semua guru Pendidikan Khas yang terlibat dalam kajian ini menggunakan M-Learning sebagai bahan bantu dalam persediaan pengajaran dan semasa pengajaran. Penggunaan M-Learning juga mampu membantu guru-guru ini meningkatkan pengetahuan dalam teknologi maklumat dan komunikasi terkini. Guru-guru Pendidikan Khas juga menggunakan M-Learning ini sebagai bahan bantu mengajar kerana maklumat dapat diakses dengan lebih mudah dan cepat. Hal ini dapat membantu melancarkan lagi pencapaian objektif dalam sesi pengajaran guru.
\end{abstract}

Kata kunci: penggunaan mobile learning, bahan bantu pengajaran dan pembelajaran, teknologi maklumat dan komunikasi

\section{M-Learning as A Teaching Aids in Special Education Classes}

\begin{abstract}
Modern technology such as mobile phones and tablets can help implement teaching using information and communication technology in education. In the field of education, the development of curriculum and pedagogy is influenced by the development of technology. Therefore, the use of Mobile Learning (M-Learning) as a teaching aid for teachers in Special Education classes is more effective and this
\end{abstract}


method can improve teachers' skills when they use the mobile phones and tablets during classes. This survey study uses a descriptive quantitative approach involving percentage, frequency, mean and standard deviation. In this study, intended method is used in this study because this study only involves Special Education teachers in a district in the state of Johor. A total of 88 samples consisting of 28 national schools, 2 national type schools and 14 secondary schools under the full administration of the Ministry of Education Malaysia. The findings show that the use, skills and attitudes of Special Education teachers towards the use of M-Learning as a teaching and learning aid are at a high level. Implications from this study show that almost all Special Education teachers involved in this study use M-Learning as an aid in teaching preparation and during teaching. The use of M-Learning is also able to help these teachers increase their knowledge in the latest information and communication technology. Special Education teachers also can use this M-Learning as a teaching aid because the information can be accessed more easily and quickly. This can help further launch the achievement of objectives in teacher teaching sessions.

Keywords: use of mobile learning, teaching and learning, information and communication technology

\section{Pengenalan}

Dalam pengajaran dan pembelajaran Pendidikan Khas, pengaruh penggunaan teknologi maklumat dan komunikasi (TMK) adalah tidak terkecuali. Penggunaan aplikasi atas talian serta pembelajaran menggunakan teknologi mampu membantu penyampaian maklumat secara terus. Dalam bidang pendidikan khas, penggunaan teknologi ini dapat memberikan impak yang lebih positif kepada perkembangan pengajaran guru dan seterusnya kepada pembelajaran murid. Hal ini kerana murid Pendidikan Khas yang mempunyai ketidakupayaan dalam pembelajaran merupakan kanak-kanak yang telah dikenalpasti ketidakupayaannya dan disahkan oleh pakar perubatan menghadapi ketidakupayaan yang boleh mengganggu guru dan rakan-rakan dalam proses pembelajaran. Murid-murid yang mengalami ketidakupayaan ini boleh dikategorikan mengikut tahap kefungsian seperti kebolehan kognitif yang rendah, mempunyai masalah tingkah laku serta perkembangan sosial yang tidak normal, penguasaan bahasa lisan dan pertuturan, keupayaan membaca serta kemahiran perkembangan. Oleh hal yang demikian, penggunaan ICT dalam pengajaran mampu memberikan rangsangan dan perubahan yang baik dalam pembelajaran murid Pendidikan Khas. Terdapat pelbagai aplikasi-aplikasi yang terdapat dalam telefon bimbit serta tablet yang mampu membantu guru untuk menjalankan pengajaran dan seterusnya mampu meningkatkan lagi pengetahuan guru dalam penggunaan teknologi moden. Hal ini seiring dengan keperluan pembelajaran murid yang dilihat mampu memberikan kesan yang lebih positif.

Dalam usaha Kementerian Pendidikan Malaysia (KPM) menyatakan respon yang positif kepada cabaran ini dengan meningkatkan pelan strategik untuk meluaskan lagi penggunaan ICT dalam pendidikan dengan menyediakan infrastruktur ICT yang mencukupi di setiap sekolah bagi menjalankan pengajaran dan pembelajaran atas talian. Selain itu, sekolah juga telah diminta dan disarankan untuk menyusun semula pentaksiran serta kurikulum dalam menerapkan elemen ICT sebagai proses pengajaran dan pembelajaran, mengadakan latihan kepada guru-guru untuk meningkatkan pengetahuan dan kemahiran mereka dalam ICT. Persekitaran pembelajaran dan pengajaran sekolah di Malaysia telah banyak berubah disebabkan oleh usaha-usaha yang dijalankan ini,. Menurut Mohd. Deni, Zainal, \& Malakolunthu, 2013, kebanyakkan bilik darjah dilengkapi dengan komputer, alat dalam talian dan projektor LCD dan juga dilengkapi dengan papan pintar dan kemudahan persidangan video. Sistem pendidikan pada masa kini dengan adanya pembelajaran mudah alih atau dikenali sebagai M-Learning telah mengalami perubahan dalam teknologi pendidikan yang semestinya juga telah memperkembangkan tahap pengajaran dalam bilik darjah.

Terdahulu, guru menggunakan kaedah pengajaran secara tradisional dan kurang menggunakan teknologi maklumat terkini. Tidak dinafikan, penggunaan kaedah pengajaran secara tradisional masih 
relevan sehingga ke hari ini namun untuk lebih menarik minat murid dan merangsang proses pembelajaran, penggunaan teknologi moden pada masa kini adalah lebih efektif. Penggunaan teknologi moden pada masa kini juga akan memudahkan pengajaran guru dalam kelas Pendidikan Khas. Penggunaan teknologi seperti M-Learning juga dikatakan mampu untuk meningkatkan pencapaian murid dalam akademik. Selain itu, guru juga secara tidak langsung dapat meningkatkan kemahiran mereka dalam penggunaan teknologi maklumat pada masa kini. Dalam membina pengetahuan dan keupayaan murid dalam pembelajaran, guru-guru juga mampu mempelbagaikan penggunaan teknologi dalam pengajaran mereka. Mereka dapat menggunakan M-Learning sebelum dan juga semasa pengajaran dan pembelajaran dijalankan. Semasa membuat persediaan mengajar, guru-guru menggunakan telefon pintar sebagai medan untuk mendapatkan maklumat terkini serta mendapatkan teknik-teknik pengajaran yang lebih baik dan mampu merangsang murid. Selain itu, guru-guru juga boleh menggunakan telefon pintar ini secara langsung dalam bilik darjah. Hal ini pasti akan lebih menarik minat murid dan mampu memberikan kesan yang lebih baik dalam pengajaran guru.

Jika sebelum ini, pengajaran dan pembelajaran dijalankan secara tradisional tanpa medan teknologi, guru-guru hanya mampu berkongsi maklumat mengenai sesuatu topik melalui buku-buku atau keratan akhbar. Bermulanya zaman teknologi moden masa kini, guru-guru boleh menggunakan M-Learning sebagai bahan bantu dalam pengajaran mereka. Guru-guru boleh berkongsi maklumat melalui gambargambar dalam bentuk 2D, 3D dan juga 4D. Selain itu, melalui penggunaan M-Learning ini juga, guruguru dapat berkongsi video-video yang berkaitan dengan topik pembelajaran yang diajar. Hal ini sudah tentu akan dapat meningkatkan minat murid sekaligus mampu merangsang pembelajaran murid. Dalam keadaan ini, murid-murid akan lebih bersemangat untuk terus belajar. Murid Pendidikan Khas sememangnya murid-murid istimewa yang perlu diberikan bimbingan dengan cara yang lebih menarik. Hal ini adalah kerana, mereka memerlukan bahan pengajaran yang lebih interaktif seperti muzik video atau gambar-gambar 4 dimensi. Murid-murid Pendidikan Khas akan lebih bersemangat jika guru-guru menggunakan bahan-bahan pengajaran berasaskan interaktif ini. M-Learning sememangnya medan yang mampu memberikan impak yang positif kepada pengajaran guru seterusnya pembelajaran murid. Namun begitu, sejauh manakah guru-guru menggunakan M-Learning ini sebagai bahan pengajaran dan pembelajaran dalam bilik darjah Pendidikan Khas.

Usaha yang berterusan ini telah ditambah baik melalui anjakan yang dilihat selaras dengan anjakan ketujuh dalam 11 anjakan utama dalam Pelan Pembangunan Pendidikan Malaysia (PPPM) (2013-2025) untuk mengubah taraf kurikulum pendidikan dengan menggunakan bahan pengajaran berbantukan teknologi. Pihak KPM juga telah menyediakan perancangan strategik untuk meningkatkan penggunaan ICT dalam pendidikan ianya dapat dilihat memberikan manfaat kepada murid-murid di sekolah. Teknik pengajaran dan pembelajaran menggunakan ICT ini harus diberikan kepada murid Pendidikan Khas juga dan tidak tertumpu dalam kelas arus perdana. Hal ini adalah kerana murid Pendidikan Khas juga perlu pengajaran dan pembelajaran yang pelbagai mengikut arus permodenan sistem.

\section{Sorotan Literatur}

Teknologi pendidikan pada masa kini adalah lebih tertumpu kepada usaha penambahbaikan prestasi dalam pengajaran dan pembelajaran. Bidang teknologi kini memberi penekanan terhadap penyelesaian masalah prestasi melalui perspektif pemikiran yang bersistem. Proses pengajaran tidak lagi tertumpu kepada satu platform pengajaran tetapi dipelbagaikan menggunakan pendekatan-pendekatan yang mampu meningkatkan lagi mutu pengurusan pengajaran secara dalam dan luar bilik darjah. Secara umumnya, M-Learning merupakan satu kaedah yang digunakan dalam pengajaran kelas Pendidikan Khas. Digunapakai menggunakan teknologi mobile yang dapat membantu proses pengajaran, membuat rujukan serta menjadi agen pencarian maklumat.

\section{Mobile Learning}

Mobile Learning atau teknologi mudah alih ini merupakan kemudahan yang telah diciptakan seperti telefon selular mudah alih. Teknologi seperti ini dapat digambarkan menerusi pembelajaran moden menggunakan teknologi mudah alih ini. Penggunaan teknologi moden masa kini seperti komputer riba 
serta telefon bimbit merupakan antara contoh bahagian yang saling melengkapi teknologi yang digunakan dalam pembelajaran M-Learning ini. Perkembangan teknologi ini memperoleh pengetahuan dengan berkolaboratif dan konvensional di mana sahaja sama ada di sekolah atau di rumah. Pengajaran secara M-Learning ini telah digunakan di negara-negara yang membangun seperti Eropah. Negaranegara ini telah lama mempraktikkan penggunaan M-Learning dalam pengajaran. Begitu juga di Malaysia, walaupun pengajaran berbantukan M-Learning masih lagi diperingkat awal, namun telah banyak kajian yang dijalankan untuk melihat keberkesanan penggunaan M-Learning dalam pengajaran. Pembelajaran secara atas talian menggunakan M-Learning adalah pembelajaran berbantukan ICT. Teknologi yang digunakan adalah seperti telefon bimbit, komputer riba dan tablet PC. M-Learning adalah sumber daripada E-Pembelajaran yang dilaksanakan sama seperti pembelajaran jarak jauh. Hal ini adalah kerana pembelajaran ini akan dikaitkan dengan internet dan tanpa wayar. Oleh hal yang demikian, pembelajaran itu boleh berlaku dimana sahaja tanpa mengira waktu dan tempat murid-murid berada.

\section{Model Pembelajaran Brown}

M-Learning ini adalah hasil daripada kaedah pembelajaran jarak jauh (d-learning) dan pembelajaran secara dalam talian (e-learning). Penggabungan kaedah ini menjadikan pengguna pembelajaran secara lebih fleksibel dan mudah alih. Hal ini akan dapat menjadikan bidang pendidikan menjadi lebih canggih dan mengikuti perkembangan semasa. Konsep M-Learning ini dijelaskan dengan lebih menyeluruh berdasarkan Rajah 1 di bawah :

\section{Rajah 1 : Model Pembelajaran}

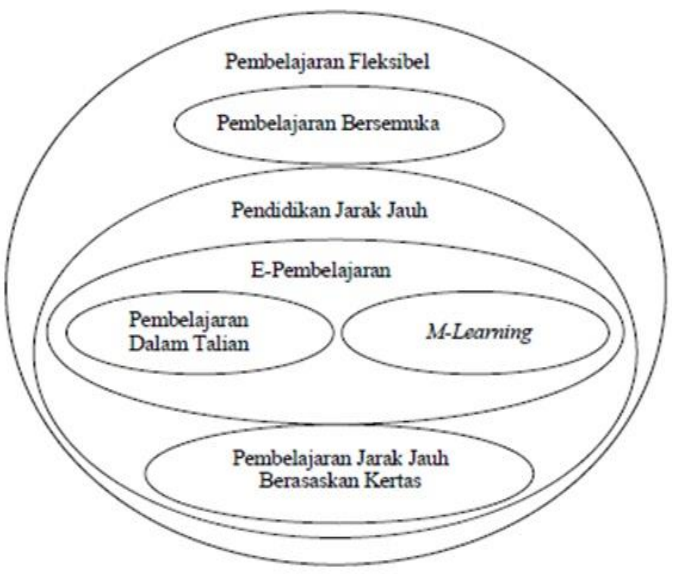

Sumber: Brown (2005)

Model Pembelajaran Brown ini menunjukkan dan menerangkan dengan jelas tentang konsep MLearning. Menurut beliau, pengajaran dan pembelajaran M-Learning merupakan subset kepada pembelajaran elektronik dimana pembelajaran elektronik itu adalah konsep makro yang melibatkan persekitaran pembelajaran dalam talian M-Learning. Menurut Brown (2005), pelajar juga boleh mengadakan aktiviti pembelajaran secara individu dan berkumpulan seperti melayari web, menjalankan program atau belajar melalui contoh permasalahan yang disediakan. Berdasarkan pernyataan ini, murid akan dapat mengakses pembelajaran dengan mudah. Guru juga boleh bersedia dengan bahan-bahan yang menarik.

Dalam kajian yang dijalankan oleh Hafiza et al. (2015) pembelajaran mobil adalah pembelajaran yang merujuk kepada persekitaran pembelajaran yang berlaku dalam lokasi dengan jangka masa yang tidak terhad serta terdiri daripada bahan pembelajaran yang tidak terkira dari pelbagai sumber melalui alat mudah alih seperti tablet atau telefon pintar. Selain itu, pengaplikasian teknologi mobil dalam pembelajaran juga dapat menyediakan pembelajaran secara seamless, ubiquitous dan context-aware yang dapat dilaksanakan dimana-mana dan pada bila-bila masa tanpa wayar (Nurul et al., 2019). Terdapat banyak kajian yang dijalankan untuk menjelaskan penggunaan M-Learning 
ini dalam pembelajaran, namun begitu, tidak terdapat lagi kajian yang dijalankan untuk menentukan penggunaan serta kemahiran guru dalam pengajaran berbantukan M-Learning.

Teknologi pada masa kini terdapat dalam pelbagai bentuk. Namun penggunaannya adalah sama dalam konteks pembelajaran. Kombinasi kerja yang berbeza akan mewujudkan perbezaan antara tujuan penggunaannya. Peralatan mudah alih ini menjadi keperluan pada masa kini yang akan memudahkan pengajaran dilaksanakan. Teknologi yang digunakan adalah seperti telefon bimbit dan tablet. Telefon bimbit dan tablet merupakan peranti tanpa wayar yang boleh digunakan dalam pengajaran M-Learning. M-Learning merupakan satu kaedah pengajaran dan pembelajaran yang menggunakan teknologi mobile dalam proses pengajaran dan pembelajaran, membuat rujukan atau medan pencarian maklumat yang berguna pada sesuatu masa (Yulius et al., 2016). Manakala menurut Chiang dan Mohd Jasmy (2016) menyatakan bahawa telefon bimbit adalah sebahagian daripada teknologi yang amat penting dalam kehidupan seharian dan agak sukar untuk melarikan diri daripada teknologi ini. Hal ini menunjukkan bahawa penggunaan M-Learning dalam pembelajaran juga merupakan pendekatan yang dapat memudahkan lagi pelaksanaan pengajaran dan pembelajaran. Pembangunan M-Learning ini merupakan pendidikan yang tidak terbatas. Penggunaan teknologi dalam pengajaran telah mampu mengubah kaedah pengajaran dengan lebih baik. Pengaplikasian teknologi ini mampu meningkatkan kemahiran pengajaran, merangsang daya intelektual murid Pendidikan Khas serta meningkatkan pencapaian murid. Penggunaan ICT juga mampu menintegrasikan pengajaran dan pembelajaran berdasarkan aspek-aspek seperti keberkesanan penggunaan ICT dalam mencapai objektif pengajaran.

Penggunaan M-Learning dalam pengajaran dan pembelajaran juga menitikberatkan kesediaan guru dalam pengaplikasian teknologi mudah alih ini. Kesediaan guru dalam penggunaan M-Learning dalam pengajaran dan pembelajaran juga merupakan hal yang sangat penting bagi memastikan objektif pengajaran dan pembelajaran dapat dicapai. Kajian Ahmad Sobri et al. (2018) menunjukkan bahawa kesediaan dalam kalangan pensyarah memberi pengaruh yang signifikan terhadap penggunaan pembelajaran mobil di Institut Pendidikan Guru Zon Utara. Guru merupakan watak utama dalam kejayaan penerapan teknologi (Papadakis, 2018) serta guru juga merupakan kunci kepada kejayaan untuk melaksanakan M-Learning yang melibatkan murid mereka dengan menggunakan pedagogi yang relevan (Miglani \& Awadhiya, 2017).

\section{Metod Kajian}

Kajian yang dijalankan ini adalah kajian kuantitatif berbentuk deskriptif bagi mengenal pasti dan mengkaji secara sistematik dan empirikal. Selain itu, objektif dan persoalan kajian adalah dilihat daripada pengetahuan guru-guru Pendidikan Khas dalam penggunaan M-Learning untuk tujuan pengajaran. Selain itu, kajian ini juga akan melihat kemahiran guru dalam penggunaan M-Learning untuk tujuan pengajaran seterusnya melihat sikap serta penerimaan guru terhadap penggunaan $\mathrm{M}$ Learning dalam pengajaran.

Kajian ini dijalankan terhadap beberapa buah sekolah yang dipilih secara rawak di sebuah daerah dalam negeri Johor, pengkaji juga menetapkan jumlah iaitu sebanyak 44 buah sekolah yang mempunyai kelas Pendidikan Khas Integrasi dalam daerah ini sebagai sampel kajian. Penyelidik telah memilih guru-guru daripada 44 buah sekolah ini sebagai sampel kajian. Oleh kerana sampel yang ada adalah terhad, pengkaji memilih persampelan kajian secara bertujuan. Pelbagai sumber maklumat telah dikaji oleh penyelidik bagi memastikan ianya bersesuaian dengan kehendak penyelidikan. Justeru, kesemua sekolah yang telah dipilih merupakan sekolah yang berada dalam daerah yang sama.

Persampelan kajian adalah terdiri daripada guru-guru Pendidikan Khas dalam sebuah daerah di negeri Johor. Guru-guru ini merupakan guru yang mengajar murid Pendidikan Khas. Kaedah persampelan yang digunakan adalah persampelan bertujuan. Hal ini adalah kerana dalam penyelidikan ini, pengkaji menentukan responden adalah yang bersesuaian dengan tujuan kajian. Berdasarkan kaedah persampelan ini, hanya guru yang mengajar kelas Pendidikan Khas sahaja yang dipilih untuk menjawab soal selidik. Namun begitu, bilangan sampel yang telah dipilih dalam kajian ini adalah 
seramai 88 orang dan mereka ini terdiri daripada guru Pendidikan Khas yang mengajar dalam kelas Pendidikan Khas.

Instrumen kajian ini telah direka dan disediakan bagi menjawab konteks dan objektif kajian ini. Borang soal selidik ini mempunyai lima bahagian iaitu Bahagian A, Bahagian B, Bahagian C, Bahagian D dan Bahagian E. Kajian ini dianalisis menggunakan kaedah menganalisis data dengan menggunakan program Statistical Package for Social Science (SPSS). Kaedah deskriptif digunakan dan semua data telah dianalisis dan dipaparkan dalam bentuk jadual yang menunjukkan peratusan, frekuensi, min dan sisihan piawai. Dalam kajian ini, pengkaji menggunakan analisis deskriptif bagi menjawab dan membincangkan hasil dapatan bagi keempat-empat bahagian.

\section{Hasil Kajian}

\section{Tahap penggunaan M-Learning sebagai bahan bantu dalam pengajaran kelas Pendidikan Khas}

Secara umumnya, hasil kajian ini menunjukkan bahawa kebanyakkan responden mempunyai tahap penggunaan yang tinggi terhadap penggunaan M-Learning. Hal ini dapat dibuktikan melalui hasil analisis soal selidik yang menunjukkan min skala bagi semua item yang berkaitan dengan tahap penggunaan M-Learning adalah melebihi 4.0. Selain itu, hampir semua responden memilih skor setuju dan sangat setuju bagi kumpulan item yang menunjukkan tahap penggunaan M-Learning sebagai bahan bantu dalam pengajaran kelas Pendidikan Khas.

Semua responden dapat menggunakan telefon bimbit dan tablet sebagai alat bantuan dalam pengajaran dan pembelajaran selain daripada alat telekomunikasi. Hal ini menunjukkan bahawa mereka mampu memuat turun dan memuat naik bahan bagi tujuan pengajaran dan pembelajaran. Selain itu, hasil daripada kajian ini juga menunjukkan bahawa semua responden dapat menggunakan alat telekomunikasi ini sebagai medan untuk mencari maklumat dan seterusnya menjalankan pengajaran dan pembelajaran sebagai M-Learning. Mereka juga mampu mempelbagaikan strategi pengajaran dan pembelajaran untuk menggalakkan proses pembelajaran dengan menggunakan M-Learning ini. Hal ini adalah disokong oleh Gary (2013) berdasarkan kajian yang telah dijalankan menunjukkan bahawa aplikasi pengajaran dan pembelajaran yang menarik pasti akan dapat membantu pelajar dalam menjana ilmu pengetahuan seterusnya memahami pembelajaran dengan lebih baik. Selain itu, murid-murid juga mampu menjana lebih banyak idea dan respon semasa pengajaran dan pembelajaran. Hal ini adalah kerana murid dapat menjalankan komunikasi dengan lebih efektif melalui pembelajaran M-Learning ini. Murid-murid juga dapat memahami setiap langkah pengajaran serta langkah-langkah penyelesaian kerana melalui pembelajaran secara M-Learning ini, pengajaran adalah lebih berstrategi. Hal ini akan lebih memudahkan murid dalam memahami konsep penting dalam pembelajaran.

Selain itu, melalui pengajaran dan pembelajaran menggunakan M-Learning ini juga hasil analisis dapatan kajian menunjukkan bahawa guru-guru mampu mempelbagaikan aktiviti pengajaran dan pembelajaran agar jadi lebih menarik. Penggunaan M-Learning ini juga mampu memberi peluang kepada guru-guru untuk mempelajari ilmu baharu mengikut perkembangan teknologi pada masa kini. Berdasarkan kajian yang dijalankan oleh Aliff dan Isa (2013) menjelaskan bahawa pengajaran dan pembelajaran menggunakan telefon bimbit ini mendapat perhatian dan sikap yang positif daripada guru-guru Pendidikan Islam serta mereka juga mendapati terdapat potensi untuk membangunkan aplikasi berbentuk mobil setelah mendapat respon yang positif terhadap responden ketika menggunakan teknologi ini dalam pembelajaran.

\section{Tahap kemahiran guru dalam penggunaan M-Learning sebagai bahan bantu dalam pengajaran kelas Pendidikan Khas}

Berdasarkan hasil dapatan kajian, tahap kemahiran guru dalam penggunaan M-Learning sebagai bahan bantu dalam pengajaran kelas Pendidikan Khas adalah sangat tinggi. Hal ini dapat dibuktikan melalui 
skor min berdasarkan bahagian item yang berkaitan dengan tahap kemahiran guru ini adalah tinggi iaitu melebihi 4.0. Hal ini menunjukkan bahawa guru-guru mempunyai kemahiran yang tinggi dalam penggunaan M-Learning ini.

Keseluruhan hasil dapatan kajian mendapati bahawa guru-guru mampu mencari maklumat menggunakan telefon bimbit atau tablet. Guru-guru ini juga menggunakan M-Learning untuk mencari maklumat mengenai bahan pengajaran dan pembelajaran dan seterusnya dapat mengakses web-web pendidikan. Hal ini akan dapat membantu guru-guru ini mengintegrasikan bahan untuk membina aktiviti pengajaran dan pembelajaran secara dalam dan luar bilik darjah. Hal ini disokong oleh kajian yang telah dijalankan oleh Hafiza et al. (2015) yang menyatakan bahawa pembelajaran mobil merujuk kepada persekitaran pembelajaran yang berlaku di pelbagai lokasi dengan jangka masa yang tidak terhad dan terdiri daripada bahan pembelajaran yang tidak terkira dari pelbagai sumber melalui alat mudah alih seperti tablet atau telefon pintar.

Melalui bahagian ini juga, dapatan dapat dilihat guru-guru kerap menggunakan M-Learning bersamasama murid dalam sesi pengajaran dan pembelajaran. Hal ini disokong oleh kajian Khairah et al. (2017), mengatakan bahawa pengaplikasian M-Pembelajaran khususnya penggunaan IM dapat membentuk sikap yang positif dalam proses pengajaran dan pembelajaran. Para pensyarah menunjukkan respon yang baik dalam penggunaan ICT untuk menjalankan aktiviti pengajaran dan pembelajaran ini. Dapatan ini turut menyokong pendapat Hartshorne dan Ajjan (2009) yang menyatakan bahawa, teknologi maklumat seperti ini dapat membantu meningkatkan lagi proses pengajaran dan pembelajaran serta interaksi antara guru dan murid dalam bilik darjah atau luar bilik darjah. Hal ini akan dapat membantu meningkatkan lagi komunikasi dua hala antara guru-guru dan murid Pendidikan Khas.

\section{Sikap guru dalam penggunaan M-Learning sebagai bahan bantu dalam pengajaran kelas Pendidikan Khas}

Berdasarkan hasil dapatan daripada kajian sikap guru dalam penggunaan M-Learning sebagai bahan bantu dalam pengajaran kelas Pendidikan Khas, dapat disimpulkan bahawa implementasi penggunaan M-Learning dalam pengajaran kelas Pendidikan Khas adalah sangat positif. Guru-guru menggunakan M-Learning sebagai medan untuk mencari rujukan serta mencari maklumat yang berkaitan dengan pengajaran dan pembelajaran kelas Pendidikan Khas pada bila-bila masa sahaja. Selain itu, M-Learning juga mampu membantu guru untuk meningkatkan minat murid dalam pembelajaran. Hal ini disokong oleh Marcelo et al. (2016), peranti mudah alih dapat menyuntik emosi yang positif kepada para pelajar. Penggunaan aplikasi dalam M-Learning dapat mempengaruhi emosi pelajar. Hal ini akan dapat menarik minat murid untuk berasa lebih teruja terhadap pembelajaran, lebih fokus, serta lebih bersemangat dalam matapelajaran Matematik. Selain itu, pengajaran dan pembelajaran secara MLearning ini dapat memberikan impak yang positif kepada murid-murid Pendidikan Khas. Mereka lebih teruja dan bersemangat menjalankan aktiviti pengajaran dan pembelajaran berasaskan teknologi ini seterusnya mewujudkan emosi yang positif. Emosi yang positif ini dapat menjadikan pelajar untuk lebih bermotivasi dalam mendalami topik yang dipelajari. Emosi positif ini juga akan dapat mempengaruhi aktiviti harian murid-murid Pendidikan Khas. Oleh hal yang demikian, penggunaan teknologi M-Learning dalam pembelajaran ini sememangnya mampu membantu guru dalam meningkatkan minat serta kesediaan murid Pendidikan Khas.

Oleh hal yang demikian, jelaslah bahawa penggunaan M-Learning dalam proses pengajaran dan pembelajaran mendapat respon dan pelbagai pihak menerima penggunaannya dengan positif. Kenyataan ini disokong dengan dapat kajian Chiang dan Mohd Jasmy (2016) yang mengatakan tahap penerimaan M-Pembelajaran dalam kalangan guru di SJKC Kuen Cheng 2 adalah tinggi. Hasil dapatan kajian yang telah dijalankan jelas menunjukkan bahawa hampir semua guru yang terlibat dalam kajian ini menjalankan pengajaran dan pembelajaran menggunakan M-Learning. 


\section{Perbincangan Kajian}

Dapatan daripada kajian ini menunjukkan bahawa penggunaan M-Learning dalam pengajaran dan pembelajaran adalah sangat positif. Melalui dapatan kajian, guru-guru banyak menggunakan MLearning dalam pengajaran bersama-sama murid. Guru-guru mahir menggunakan M-Learning sebagai medan untuk mempelbagaikan aktiviti dan dapat diterokai dengan meluas di samping memperoleh pengetahuan secara kolaboratif dan konvensional di mana sahaja seperti dalam bilik darjah. Hal ini adalah sejajar dengan Model Pembelajaran Brown yang menunjukkan dan menerangkan dengan jelas tentang konsep M-Learning. Menurut beliau, pengajaran dan pembelajaran M-Learning merupakan subset kepada pembelajaran elektronik dimana pembelajaran elektronik itu adalah konsep makro yang melibatkan persekitaran pembelajaran dalam talian M-Learning. Menurut Brown (2005) pelajar juga boleh mengadakan aktiviti pembelajaran secara individu dan berkumpulan seperti melayari web, menjalankan program atau belajar melalui contoh permasalahan yang disediakan. Berdasarkan pernyataan ini, murid akan dapat mengakses pembelajaran dengan mudah. Guru juga boleh bersedia dengan bahan-bahan yang menarik. Guru dapat menjadi pemudahcara kepada murid untuk menjalankan aktiviti bersama-sama dan mewujudkan pembelajaran secara kolaborasi antara guru dan murid.

Kajian yang telah dilaksanakan ini dapat memberikan sumbangan keilmuan dalam bidang pengajaran dan pembelajaran menggunakan teknologi maklumat dan komunikasi terutama dalam penggunaan telefon bimbit dan tablet. Kajian ini juga menyokong kepentingan dan menghasilkan implikasi yang sangat positif terhadap sektor pendidikan di Malaysia khususnya kepada penggunaan, tahap kemahiran serta sikap guru dalam penggunaan M-Learning di kelas Pendidikan Khas. Dapatan kajian menunjukkan bahawa penggunaan M-Learning dalam pengajaran dan pembelajaran kelas Pendidikan Khas adalah sangat tinggi. Guru-guru tahu menggunakan dan sering menggunakan kaedah ini bagi mencari malumat serta menjalankan pengajaran berbantukan M-Learning. Penggunaan M-Learning dalam pengajaran dan pembelajaran ini merupakan teknologi mudah alih yang mampu membantu memudahkan tugas guru serta mampu mewujudkan persekitaran pembelajaran yang positif. Hal ini adalah selaras dengan kehendak Pelan Pembangunan Pendidikan Malaysia (PPPM) 2013-2025 yang menyatakan hasrat kementerian dalam memanfaatkan teknologi maklumat dan informasi untuk meningkatkan kualiti pembelajaran dalam Negara kita. Ia juga berperanan sebagai pemacu bagi mencapai Wawasan 2020 Malaysia untuk menjadikan Malaysia sebagai peneraju teknologi maklumat dan komunikasi di peringkat antarabangsa (Ghavifekr et al., 2016). Penggunaan M-Learning dalam pengajaran dan pembelajaran juga dapat melahirkan para pendidik yang celik teknlogi juga mampu bersaing dengan perkembangan teknologi semasa. Hal ini akan dapat membantu pihak kementerian untuk menghasilkan tenaga kerja yang celik teknologi, berfikir secara kritis, bersedia untuk melibatkan diri dengan sepenuhnya dalam ekonomi global abad ke-21 (Ghavifekr \& Mohammed Sani, 2015). Sehubungan dengan itu, kajian ini telah berjaya membuktikan bahawa pengaplikasian teknologi maklumat dalam pengajaran dan pembelajaran telah dijalankan oleh guru-guru Pendidikan Khas dalam dan luar bilik darjah. Hal ini selaras dengan kehendak Kementerian Pendidikan Malaysia (KPM) yang telah menekankan kepentingan menerapkan penggunaan teknologi maklumat dan komunikasi dalam aktiviti pembelajaran dan pemudahcaraan. Pengaplikasian teknologi maklumat dan komunikasi bukan sahaja mendorong pelajar menjadi kreatif, malah menjadikan aktiviti penimbaan ilmu pengetahuan dalam kalangan pelajar-pelajar lebih menarik dan menyeronokkan (KPM 2016).

Selain itu, dapatan kajian juga diharapkan dapat membantu pihak-pihak tertentu seperti Jabatan Pendidikan Negeri (JPN) serta Pejabat Pendidikan Daerah (PPD) untuk melihat dan menilai penggunaan M-Learning dalam kalangan guru Pendidikan Khas. Guru Pendidikan Khas mampu menggunkan M-Learning dalam pembelajaran dan hal ini juga dapat membantu pihak JPN dan PPD untuk merancang program-program pembangunan, seminar, kursus atau persidangan perkongsian idea berasaskan teknologi agar dapat memberikan lebih banyak maklumat ilmu kepada guru-guru. Perkara ini secara tidak langsung dapat meningkatkan pengetahuan dan kemahiran guru dalam penggunaan MLearning sebagai medan pengajaran dan pembelajaran.

Sebagai seorang pendidik yang berwawasan, kita perlu mempunyai inisiatif untuk meningkatkan tahap pengetahuan, kemahiran dan sikap dalam penggunaan teknologi pada masa kini. Dalam pelaksanaan 
pengajaran dan pembelajaran, guru perlu sentiasa bersedia dengan perkembangan teknologi yang mampu memberikan kemudahan kepada guru. Penggunaan kaedah pengajaran memainkan peranan yang penting kerana setiap murid Pendidikan Khas adalah berbeza. Mereka memerlukan pendekatan dan kaedah yang berbeza-beza dalam menjalankan pembelajaran. Selain itu, mereka juga memerlukan pendekatan yang mampu menarik perhatian serta meningkatkan kebolehan kognitif mereka selaras dengan kecenderungan mereka. Oleh hal yang demikian, penggunaan M-Learning ini dapat membantu guru untuk mencari maklumat seterusnya mempelbagaikan lagi kaedah pengajaran murid-murid berkeperluan khas ini.

Amalan pengajaran dan pembelajaran berbantukan M-Learning ini adalah proses pengajaran dan pembelajaraan yang mampu bersaing dengan negara-negara maju yang lain. Proses pengajaran dan pembelajaran ini adalah menekankan pengembangan amalan seperti pengetahuan guru dalam menggunakan alatan sumber digital dan peranti mudah alih, akses internet serta sokongan daripada semua pihak termasuk pihak pentadbiran sekolah. M-Learning ini juga boleh dimanfaatkan oleh semua lapisan masyarakat. Oleh hal yang demikian, bagi cadangan untuk kajian masa depan, dapat dilihat melalui kesediaan murid itu sendiri dalam menggunakan M-Learning dalam pembelajaran. Selain itu, kajian juga dapat diteruskan dengan melihat penggunaan M-Learning di kawasan luar Bandar yang mempunyai capaian internet yang sangat lemah.

\section{Kesimpulan}

Analisis statistik menunjukkan bahawa penggunaan, kemahiran dan sikap guru Pendidikan Khas dalam menggunakan M-Learning sebagai bahan bantu pengajaran dan pembelajaran adalah tinggi. Guru-guru berjaya menggunakan M-Learning dalam kelas Pendidikan Khas serta mampu mempelbagaikan kaedah pengajaran melalui M-Learning ini. Dalam pengajaran dan pembelajaran menggunakan M-Learning ini telah mendapat penerimaan yang sangat positif daripada guru-guru. Perkembangan kemajuan teknologi pada masa kini dapat memberikan peluang kepada guru-guru dan murid-murid untuk belajar dan mendapatkan maklumat dengan lebih meluas tidak mengira masa dan lokasi. Inilah canggihnya teknologi tanpa wayar pada masa kini. Semua maklumat dapat disalurkan di hujung jari.

Melalui perkembangan pembelajaran melalui M-Learning ini pembelajaran berasaskan teknologi canggih adalah tidak sukar untuk diimplementasikan di Negara ini. Hal ini sudah pasti dapat melahirkan murid-murid Pendidikan Khas yang mampu menguasai pembelajaran serta membantu murid-murid Pendidikan Khas dalam menguasai kemahiran generik secara asasnya. Disamping itu juga berdasarkan dapatan kajian yang diperoleh dapat dirumuskan bahawa pelaksanaan pengajaran dan pembelajaran menggunakan teknologi ini adalah lebih jimat dan tidak memerlukan penggunaan kos yang tinggi namun guru-guru perlu bijak mencari maklumat dan memanfaatkan teknologi yang ada. Guru-guru perlu bijak mendapatkan maklumat yang berguna dan sentiasa berusaha mempelajari teknologi baharu bagi memudahkan lagi pengajaran dan pembelajaran mereka.

\section{Rujukan}

Amran N. \& Rosli R. (2017). Kefahaman Guru Tentang Kemahiran Abad Ke-21. Universiti Kebangsaan Malaysia.

Abdul Fattah Bin Mat Nang, Siti Mistima Binti Maat (2018). Gamikasi : Satu Kaedah Pengajaran dan Pemudahcaraan PAK 21. ICOFEA 2018 Conference Proceeding eISBN 978-967-14616-2-4.

Ahmad Sobri Shuib, Muhammad Nidzam Yaakob \& Azizah Sarkowi. (2018). Pengaruh pengalaman teknologi, peluang dan kesediaan terhadap penggunaan mobile learning di institut pendidikan guru zon utara. Jurnal Penyelidikan Dedikasi, 14, 143-166.

Al-Husain, Dalal., \& Hammo, B. H. (2015). Investigating the readiness of college students for ict and mobile learning: A case study from king saud university. International Arab Journal of $e$ Technology, 4(1), 48-55. 
Aliff Nawi, Mohd Isa Hamzah \& Azwin Arif Abdul Rahim. (2015). Teachers acceptance of mobile learning for teaching and learning in islamic education: A preliminary study. Turkish Online Journal of Distance Education, 16(1), 184-192.

Almutairy, S., Davies, T., \& Dimitriadi, Y. (2015). Students' perceptions of their m-learning readiness. Journal of Electronics and Communication Engineering, 9(5), 1464-1467.

Arlina Ahmad Zaki. \& Melor Yunus. (2015). Potential of mobile learning in teaching of esl academic writing. Canadian Center of Science and Education, 8(6), 11-19.

Badrul Hisham, Mohd Nasruddin 2016. Amalan Pengajaran dan Pembelajaran Abad Ke 21 Dalam Kalangan Pensyarah Institut Pendidikan Guru Kampus Ipoh. Jurnal Penyelidikan Dedikasi Jilid 10, 2016.

Baş, M., \& Sarıgöz, O. (2018). Determining the readiness levels of pre-service teachers towards mobile learning in classroom management. Education Research and Reviews, 13(10), 382-390.

Chaka, J. G., \& Govender, I. (2017). Students' perceptions and eadiness towards mobile learning in colleges of education: A nigerian perspective. South African Journal of Education, 37(1), 1-12.

Chen, C. H., Chiu, C. H., Lin, C. P., \& Chou, Y. C. (2017). Students' attention when using touchscreens and pen tablets in a mathematics classroom. Journal of Information Technology Education: Innovations in Practice, 16, 91-106.

Creswell, J. W. (2014). Research design: Qualitative, quantitative, and mixed methods approaches (4th ed.). Thousand Oaks, CA: Sage Publications.

Dewan Bahasa dan Pustaka 2007. Kamus Dewan Edisi ke-empat. Dewan Bahasa dan Pustaka. Kuala Lumpur.

Faridah Nazir. 2016. Pengajaran dan Pembelajaran Abad Ke 21. Selangor :Penerbit Sasbadi Sdn. Bhd.Ghavifekr, S., \& Mohammed Sani. (2015). Effectiveness of ICT integration in Malaysian schools: A quantitative analysis. International Research Journal for Quality in Education, 2(8), $1-12$.

Ghavifekr, S., Kunjappan, T., Ramasamy, L., \& Anthony, A. (2016). Teaching and learning with ICT tools: Issues and challenges from teachers' perceptions. Malaysian Online Journal of Educational Technology, 4(2), 38-57.

Hafiza Abas, Faridah Hanim Yahya \& Mahamsiatus Kamaruddin. (2015). User readiness evaluation of qr codes in mobile learning (m-Learning). Proceeding of International Conference on Information Technology \& Society, 126-136.

Huang Ji Xiang, Zanaton Hj Iksan. 2019. Kefahaman Guru Sekolah Rendah Daerah Pekan Terhadap Pembelajaran Abad Ke-21 (PAK21). Universiti Kebangsaan Malaysia. Proceeding : International Conferencee Humanities, Education and Society (ICHES 2019).

Iqbal, S., \& Bhatti, Z. A. (2015). An investigation of university student readiness towards m-learning using technology acceptance model. International Review of Research in Open and Distributed Learning, 16(4), 83-103.

Kamus Dewan. (2007). Edisi keempat. Kuala Lumpur : Dewan Bahasa dan Pustaka.

Kementerian Pendidikan Malaysia. (2016). Kurikulum Standard Sekolah Rendah: Dokumen Standard Kurikulum dan Pentaksiran Matematik Tahun 2. Putrajaya: Kementerian Pendidikan Malaysia.

Khoo, Y. Y., \& Fitzgerald, R. (2015). Pocket learning: A new mobile learning approach for distance learners. International Journal of Mobile Learning and Organisation, 9(3), 271-283.

Kementerian Pendidikan Malaysia 2013. Pelan Pembangunan Pendidikan Malaysia 2013-2025 (Pendidikan Prasekolah hingga Lepasan Menengah). Putrajaya. Kementerian Pendidikan Malaysia.

Kementerian Pendidikan Malaysia. 2016.Garis Panduan Sekolah Amanah, Bahagian Pengurusan Sekolah Harian, Kementerian Pendidikan Malaysia. Putrajaya. Yayasan Amir \& LeapEd.

Malike Brahim \& Musliza Mohamad. (2018). Awareness, readiness and acceptance of the students' in polytechnic of sultan abdul halim mu'adzam shah on m-learning. Asian Journal of Sociological Research, 1(1), 21-33.

Meizareena Mizad, Zailin Shah Yusoff, Zainal Abidin Sayadi, Azmi Abdul Latif \& Safra Liyana Sukiman. (2018). Students readiness and motivation to use mobile phone for learning english at higher learning institution. International Journal of Asian Social Science, 8(11), 1077-1087.

Miglani, A., \& Awadhiya, A. K. (2017). Mobile learning: Readiness and perceptions of teachers of open universities of commonwealth asia. Journal of Learning for Development, 4(1), 58-71. 
DOI: https://doi.org/10.47405/mjssh.v6i5.781

Mohammad Shorfuzzaman \& Musaed Alhussein. (2016). Modeling learners' readiness to adopt mobile learning: A perspective from a gcc higher education institution. Mobile Information System, 2016(3), 1-10.

Moher, D., Liberati, A., Tetzlaff, J., \& Altman, D. G. (2009). Preferred reporting items for systematic reviews and meta-analyses: The prisma statement. Journal of Clinical Epidemiology. 62: 10061012. https://doi.org/10.1016/j.jclinepi.2009.06.005

Moosavi, Z. H., DeWitt, D., \& Naimie, Z. (2018). EFL undergraduate learners' readiness towards mobile learning. Proceeding of the 4th International Conference on Education, 4(2), 121-128.

Nurzarina Amran dan Roslinda Rosli. 2017. Kefahaman Guru Tentang Kemahiran Abad Ke 21. Persidangan Antarabangsa Sains Sosial dan Komunikasi.

Nik Ahmad N.N.A. 2015. Pendidikan Kelas Abad Ke 21. Dewan Bahasa dan Pustaka Wilayah Timur. SInar Harian Sdn Bhd.

Normaliza Abd Rahim . 2014. The nearly forgotten Malay folklore: Shall we startwith the software? TOJET: The Turkish Online Journal of EducationalTechnology, 13 (3), 216-221.

Wan Faizal Ismayatim dan Suzianah Jiffar.2016. Bersedia Hadapi Cabaran Pembelajaran Abad Ke 21. Berita Harian Online. Diambil pada 8 April 2020, daripada https://www.bharian.com.my/node/154117

MyGuru, Universiti Pendidikan Sultan Idris (UPSI). Dirujuk pada 28 Mac 2020, dari https://myguru2.upsi.edu.my/login.php.

Quizlet: Simple free learning tools for students and teachers. Dirujuk pada 29 Mac-04 April 2020, dari http://quizlet.com/. 